\title{
Effect of Bariatric Sleeve Gastrectomy Technique on Women's Lower Urinary Tract Symptoms and Quality of Life: A Prospective Study
}

\author{
Bariatrik Sleeve Gastrektomi Tekniğinin Kadın Alt Üriner Sistem \\ Semptomları ve Yaşam Kalitesi Üzerine Etkisi: ProspektifBir Çalışma
}

\author{
Fatih Uruç1, Serkan Akan1, Bekir Aras2, Aytaç Şahin1, Elif Uruç3, Özgür Haki Yüksel1, \\ Ahmet Ürkmez1, Çağlar Yıldırım1
}

1Fatih Sultan Mehmet Training and Research Hospital, Clinic of Urology, İstanbul, Turkey

2Dumlupınar University Faculty of Medicine, Department of Urology, Kütahya, Turkey

3Fatih Sultan Mehmet Training and Research Hospital, Clinic of Obstetric and Gynecology, Istanbul, Turkey

\section{What's known on the subject? and What does the study add?}

The effect of bariatric surgery on lower urinary tract symptoms in obese women.

\begin{abstract}
Objective

Obesity triggers lower urinary tract symptoms (LUTS) secondary to accumulation of excess fat which may lead to increase in intra-abdominal/ intravesical pressures and subsequent impairment in pelvic floor muscles. However, it is considered that weight loss resolve these symptoms. In this study, we aimed to investigate the effects of bariatric surgery and especially Sleeve gastrectomy (SG) on women's LUTS, and quality of life.
\end{abstract}

\section{Materials and Methods}

A total of 53 patients who have undergone laparoscopic SG in our clinics between April 2014 and March 2015 were included in this prospective study. Age, body weight and body mass index (BMI) of the participants were preoperatively and postoperatively recorded. The patients have pre/ post-operatively filled the Beck depression inventory (BDI), International prostate symptom score (IPSS), International Consultation on Incontinence Questionnaire-Short Form (ICIQ-SF) and the 36-Item Short Form health survey (SF-36) scores were recorded. Additionally, post-operative decrease in body weight and BMI of the patients was recorded.

\section{Results}

There was a statistically significant decrease in mean BDI, IPSS and ICIQ-SF scores and SF-36 (prominent increment in physical and mental

\section{ÖZ}

Amaç

Obezite; yağlanma artışı nedeniyle intraabdominal/intravesikal basınçta artışa neden olarak pelvik taban kaslarını zayıflatır ve alt üriner sistem semptomlarının (AÜSS) oluşmasını tetikler. Kilo kaybının ise bu semptomlarda düzelmeye yol açacağına inanılmaktadır. Bizim bu çalışmadaki amacımız günümüzde gittikçe artan sayılarda uygulanan bariatrik cerrahinin özellikle Sleeve gastrektomi (SG) tekniği uygulanarak sağlanan kilo kaybının kadınlarda AÜSS ve yaşam kalitesine olan etkilerini araştırmaktır.

Gereç ve Yöntem

Nisan 2014 ila Mart 2015 tarihleri arasında merkezimizde obezite nedeniyle laparoskopik SG cerrahisi geçiren hastalardan dışlama kriterleri sonrasında uygun olan 53 kadın hasta çalışmaya dahil edildi. Hastaların operasyon öncesi yaş, boy, kiloları ve vücut kitle indeksleri (VKI) preoperatif ve postoperatif olarak kaydedildi. Hastalara preoperatif ve postoperatif olarak Beck depresyon ölçeği (BDI), Uluslar arası prostat semptom skoru (IPSS), Uluslar arası idrar kaçırma sorgulama formu (ICIQSF) ve short form-36 (SF-36) doldurularak verileri kaydedildi. Ayrıca hastaların operasyon sonrası kilo kayıpları ve VKi düşüşleri de kaydedildi.

\section{Correspondence}

Fatih Uruç MD, Fatih Sultan Mehmet Training and Research Hospital, Clinic of Urology, İstanbul, Turkey

Phone: +90 2165783000 E-mail: urucmd@gmail.com Received: 23.05.2016 Accepted: 31.07.2016

This study was 14-17 October National Urogynecology Congress, 2015 İstanbul. 
component summary (PCS and MCS) scores), when compared with pre-operative values. A positive correlation was found between BMI and parameters including age, BDI and IPSS. However, no significant correlation was present between $\mathrm{BMI}$ and the parameters including ICIQSF, PCS and MCS.

\section{Conclusion}

Negative effect of obesity on LUTS and quality of life cannot be ignored. We assume that bariatric surgery can induce dramatic weight loss, amelioration in symptoms of urinary dysfunction and increase in quality of life of women.

\section{Keywords}

Obesity, lower urinary system, bariatric surgery, Sleeve gastrectomy, quality of life

\section{Bulgular}

Operasyon öncesine göre operasyon sonrası BDI, IPSS, ICIQ-SF ortalamalarında görülen düşüş ve SF-36'nın mental ve fiziksel ortalama skorlarında görülen artış istatistiksel olarak anlamlı bulundu.

\section{Sonuç}

Bu çalışmada bariatrik obezite cerrahisinin kadınlarda dramatik kilo kaybı ile birlikte AÜSS üzerinde düzelme ve yaşam kalitesinde artış sağlayabileceğini düşünmekteyiz.

\section{Anahtar Kelimeler}

Obezite, alt üriner sistem, bariatrik cerrahi, Sleeve gastrektomi, yaşam kalitesi

\section{Introduction}

Obesity is among the most important problems both in developed and developing countries due to its related comorbidities. From the year 1980 up to now, the number of obese individuals has increased nearly two-fold. Based on 2008 data of The World Health Organization, 1.6 billion overweight adults are living worldwide. This figure also includes 300 million obese female individuals $(1,2)$. In the United States, approximately $67 \%$ of the population is either overweight or obese, whereas the prevalence of obesity is $40-50 \%$ in many European countries (3). More than 40 million children under five years of age were overweight according to 2011 data $(1,2)$. It is estimated that there are 500 million obese adults globally and this number is increasing every year. Annually, nearly 2.8 million people are lost because of the complications related to obesity (4). The Turkish Diabetes Epidemiology Study-I (TURDEP-I), reported that the prevalence of obesity was 22.3\% in 1997 (5). However, it has been reported in TURDEP-II that the obesity rate raised up to $32 \%$ in 2010 and this fact reflects a worrisome increment (6). Although it is possible to lose weight using non-surgical methods, within a short time, such as 24 months, 66\% of patients regain their lost weight. Patient's compliance to diet during medical treatment can give an idea about the postoperative compliance of the patient to the prescribed treatment. Since comorbidities associated with obesity result in premature deaths. Surgery has become the first choice in the treatment of morbid obesity (7). Nowadays, bariatric surgery is the only treatment modality which produces $15 \%$ weight loss in long term (8). When mortality, morbidity, cost, patient's satisfaction and, most importantly, amount of weight loss are considered, laparoscopic Sleeve gastrectomy (LSG) is one of the most frequently preferred surgical procedures $(9,10)$. In the USA, nearly more than 220.000 of bariatric surgical procedures are being performed annually (11). Theoretically, obesity triggers lower urinary tract symptoms (LUTS) due to accumulation of excess fat, leading to increases in intra-abdominal and intravesical pressures and resultant weakening of pelvic floor muscles. However, weight loss is thought to resolve these symptoms $(12,13,14)$. In this study, we aimed to investigate the effect of weight loss achieved by bariatric surgery, especially using LSG technique, on women's LUTS and quality of life.

\section{Materials and Methods}

A total of 53 female obese patients who underwent LSG between April 2014 and March 2015 were included in this prospective study. Ethical approval was obtained from the Local Ethics Committee prior to commencing the study. Patients who did not give informed consent, those with a history of treatment for sexual dysfunction, with a known mental or psychiatric disease, a history of weight loss treatment, surgery for incontinence, medical treatment for LUTS, respiratory tract diseases (e.g. chronic obstructive pulmonary disease) or a neurological disorder which might be associated with urinary symptoms, and those younger than 18 years of age were excluded. 53 female patients were included in this study and pre- and postoperative data were evaluated. Preoperative data on age, height, body weight and body mass index (BMI) were recorded. Before and after the operation ( 6 months after surgery) the patients completed the International prostate symptom score (IPSS), International Consultation on Incontinence Questionnaire Short Form (ICIQ-SF), Beck depression inventory (BDI) and the 36-Item Short Form health survey (SF-36), and the scores were recorded. Besides, postoperative decrease in body weight and BMI were determined in all patients. All the participant patients were advised to follow the dietary program according to the bariatric surgery diet guidelines for six months before and after the surgical intervention and to avoid some foods, such as caffeine, spices and citrus fruits which may cause irritation in the bladder.

IPSS: Its former name was American Urological Association Symptom Index. This scoring system consists of 8 items, which are rated as mild (0-7), moderate (8-19) and severe (20-35) symptomatic. Severity of symptoms and their progression within a specific time period are compared.

ICIQ-SF: This scoring system measures severity and effects of symptoms of incontinence on quality of life and contains 4 questions. The cut-off scores are as follows: slight $=1-5$, moderate $=6-12$, severe $=13-18$ and very severe $=19-21$.

BDI: It is a multiple-choice self-assessment scale consisting of 21 items used to measure severity of anxiety in children and adults. The levels of anxiety are scored as follows: $0-13=$ minimal depression, 14$19=$ mild depression and 20-28=moderate depression, 20-63=severve depression. 
SF-36: This is a reliable and very frequently used validated scale in the evaluation of health status and quality of life. The scale consists of 36 items and enables measurements of 8 domains which include vitality, physical functioning, bodily pain, general health perceptions, physical role functioning, emotional role functioning, social role functioning, and mental health. Scoring is summarized under two headings namely Physical summary scores (PCS) and Mental summary scores (MCS).

Surgical technique: SG was firstly started to be performed as a restrictive component of duodenal switch operation. It was introduced into surgical practice as a risk-decreasing method in highrisk patients who cannot tolerate prolonged procedures (15). LSG has become a safe and effective primary method of bariatric surgery, which has gained high popularity among surgeons and patients (16). In this method, a narrow tubular neo-stomach is constructed. Greater curvature is freed from $2-3 \mathrm{~cm}$ proximal to the pylori up to "His angle" (incisuracardiaca), then gastric resection is realized. In order not to leave a large fundus pouch behind, posterior dissection should be very well performed so as to make His angle visible. Sleeve tube is fixated by suturing it to the omentum or gastrocolic adipose tissue. This procedure prevents kinking of the stomach from incisura angularis. Restrictive nature of $\mathrm{LSG}$, decrease in ghrelin hormone production, rapid passage of food into distal segments and increase in peptideYY and glucagone-like peptide-1 hormones are thought to induce weight loss $(17,18)$. LSG is preferred in super obese patients, and those with a BMI of $<50 \mathrm{~kg} / \mathrm{m}^{2}$ who want to be operated with this method. In a systemic analysis of 2.500 patients (median BMI: $51.2 \mathrm{~kg} / \mathrm{m}^{2}$ ) who had been operated with this method, the average weight loss was $55 \%$, complication rate was $8 \%$, and mortality rate was $0.19 \%$ (19). Diabetes remission rate was found to be $66.2 \%$ among patients who underwent LSG and it was thought that 15\% these patients might again require a bariatric intervention at a later date $(20,21)$. LSG has become a very frequently preferred method alone or in combination with other methods in the treatment of morbid obesity (22).

\section{Statistical Analysis}

The study was planned as a prospective trial. For statistical analysis of the results obtained in the study, SPSS Statistics 22 (IBM, Chicago, USA) program was used. The fitness of parameters to normality of distribution was evaluated using the Shapiro-Wilks test. In the comparison of the study data, descriptive statistical methods (mean, standard deviation) were used. Besides, for intergroup comparisons of quantitative data with normal distribution Student's t-test and those with non-normal distribution, the Mann-Whitney $U$ test were used. A p-value of less than 0.05 was considered statistically significant. For intra group comparisons of parameters with normal distribution, the paired samples t-test, and for parameters with nonnormal distribution, the Wilcoxon signed-rank test was used. In the analysis of correlations between parameters with normal distribution, Pearson's correlation analysis was employed.

\section{Results}

The study was performed on 53 female patients who underwent LSG between April 2014 and March 2015. The mean age of the subjects was $34.85 \pm 9.38$ years (range: $18-54$ ) (Table 1). Statistically significant decreases in average postoperative BMI values, BDI scores, body weights, IPSS, and ICIO-SF scores were detected relative to the preoperative estimates (for all, $p=0.001$ ). When compared with preoperative values, statistically significant increases were observed in average postoperative PCS and MCS (for all, $p=0.001$ ) (Table 2). When compared with preoperative values, a positive correlation at a level of 29.5\% was found between postoperative amount of percent change in BMls and age $(p=0.032)$. When compared with preoperative values, there was no statistically significant correlation between postoperative amount of percent change in BMIs, and changes in ICIQ-SF, PCS and MCS values $(p=0.054)$. When compared with preoperative values, a statistically significant positive correlation was observed at a level of $27.8 \%$ between postoperative amount percent change in BMIs, and changes in BDI scores $(p=0.044)$. When compared with preoperative values, a statistically significant positive correlation was found at a level of 33.5\% between postoperative amount of percent change in BMls and changes in IPSS values $(p=0.014)$ (Figure 1).

\section{Discussion}

Theoretically, obesity triggers LUTS due to accumulation of excess fat which causes increases in intraabdominal and intravesical pressure

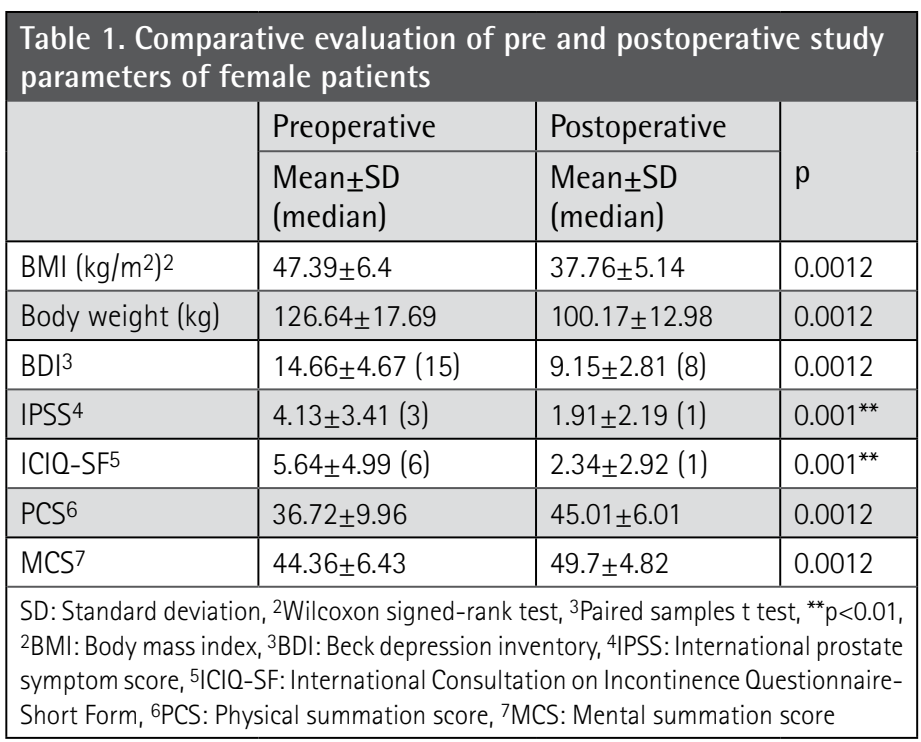

Table 2. Evaluation of percent changes detected in postoperative Body mass index values relative to preoperative values and their correlations with changes in some selected parameters

\begin{tabular}{|l|l|l|}
\hline \multirow{2}{*}{$\begin{array}{l}\text { Postoperative changes in some postoperative } \\
\text { parameters relative to preoperative values }\end{array}$} & \multicolumn{2}{|l|}{$\begin{array}{l}\text { BMI2 percent } \\
\text { change }(\%)\end{array}$} \\
\cline { 2 - 3 } & $r$ & $p$ \\
\hline Age (years) & 0.295 & $0.032^{*}$ \\
\hline BDI3 & 0.278 & $0.044^{*}$ \\
\hline IPSS4 & 0.335 & $0.014^{*}$ \\
\hline ICIO-SF5 & 0.266 & 0.054 \\
\hline Body weight & 0.859 & $0.001^{* *}$ \\
\hline PCS6 & -0.244 & 0.078 \\
\hline MCS7 & -0.266 & 0.055 \\
\hline Peason corre & &
\end{tabular}

Pearson correlation analysis ${ }^{*} p<0.05,{ }^{* *} p<0.01$, SD: Standard deviation, ${ }^{2}$ Wilcoxon signed-rank test, ${ }^{3}$ Paired samples $t$ test, ${ }^{* *} p<0.01$ 2BMI: Body mass index, ${ }^{3} \mathrm{BDI}$ : Beck depression inventory, 4 IPSS: International prostate symptom score, 5ICIQ-SF: International Consultation on Incontinence Questionnaire-Short Form, 6PCS: Physical summation score, ${ }^{7}$ MCS: Mental summation score 


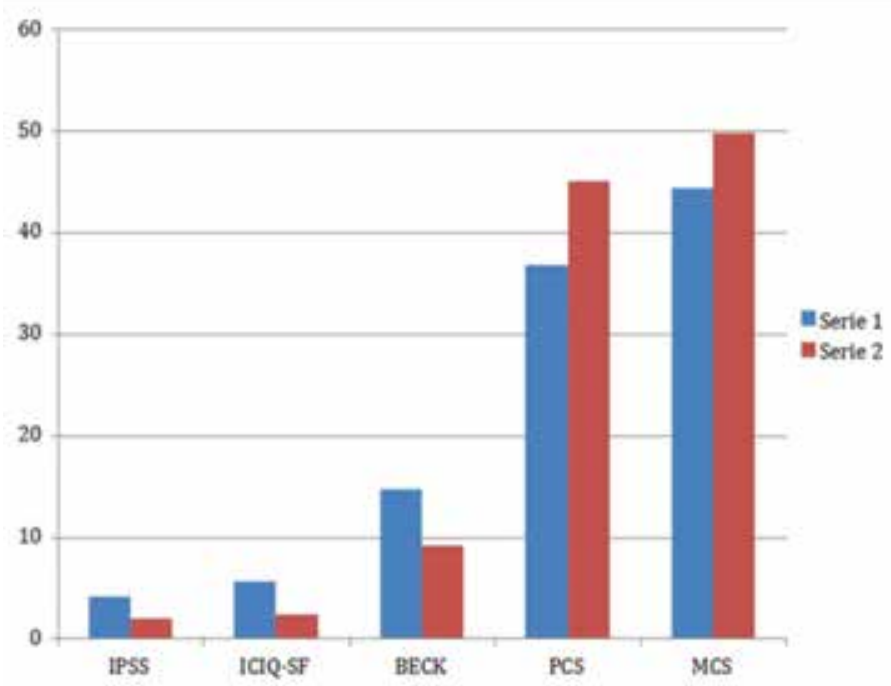

Figure 1. Comparative evaluation of pre and postoperative International prostate symptom score, International Consultation on Incontinence Questionnaire-Short Form, Beck depression inventory, physical component summary and mental component summary of patients

Serie 1: Pre-gastrectomy, Serie 2: Post-gastrectomy, IPSS: International prostate symptom score, ICIQ-SF: International consultation on incontinence questionnaire short form, BECK: Depression inventory scoring, PCS: Physical summary scores, MCS: Mental summary scores

and resultant weakening of pelvic floor muscles. However, weight loss is thought to resolve these symptoms (12-14).

Vella et al. (23) underlined BMI as an independent risk factor for urinary system symptoms. In our study, a significant correlation could not be found between change in $\mathrm{BMI}$, and ICIQ-SF, while a positive correlation was detected between changes in BMI, and IPSS scores.

Ranasinghe et al. (24) performed laparosopic gastric banding in 653 female patients, and reported postoperative improvements in their ICIQ-SF scores. In our study, we also detected improvements in postoperative ICIQ-SF scores when compared with the preoperative values.

Palleschi et al. (25) reported higher incidence of overactive bladder symptoms in obese people and asserted that women were more severely affected by these symptoms. They recorded improvements in overactive bladder symptoms in patients who had undergone LSG at the 6 . postoperative month.

In their study on 421 cases, Merrell et al. (26) reported that women with pelvic floor deformities had higher psychiatric concerns about the postoperative outcomes of bariatric surgery relative to other candidates of bariatric surgery. However, in our study, evaluations performed by means of $\mathrm{BDI}$ and we observed that preoperative high BDI scores had decreased and hence improved during the postoperative period.

Snyder et al. (27) analyzed physical and mental quality of life of women athletes and non-athletes in the year 2010 and found that average PCS and MCS sin control group were 53.3 and 46.6, respectively.

However, in our study, average preoperative PCS and MCS in obese participants were found to be 36.72 and 44.36 , which were apparently lower than the average scores detected in normal population. Whereas, postoperative PCS and MCS statistically significantly improved, and raised to 45.01 and 49.7 points, respectively.

IPSS rating scale was not used in LUTS evaluation in the current study. However, it has also been reported in the literature that IPSS, which was a well-known approach in evaluation of the male patients, was used in female patients. In our study, IPSS rating scale was applied for LUTS of our patients and, after assessments, the patients were categorized in the mildly symptomatic (0-7) group. However, when compared with the preoperative values, the decrease in postoperative mean IPSS scores was statistically significant. Besides, a statistically significant and positive correlation at a level of 33.5\% was found between amount of percent change in BMI and changes in IPSS scores. In our study in female patients who had undergone LSG and lost weight, LUTS ameliorated with resultant improvement in patients quality of life.

In the future, studies incorporated with urodynamic studies, which will explain postoperative improvements in LUTS following bariatric surgery, and relevant correlations should be conducted.

Unfavorable effects of increasingly prevalent obesity on sexual functions cannot be denied. We assume that bariatric surgery induces dramatic weight loss, and also decreases urinary dysfunction in women with resultant improvement in their quality of life.

Disclosure: We hereby certify that the present study was not supported by an institutional funding or a private enterprise in any circumstances. All study expenses and charges were covered by the authors themselves.

\section{Ethics}

Ethics Committee Approval: 2014/16 study, Fatih Sultan Mehmet Training and Research Hospital-Local Ethics Committee 2014/36, Informed Consent: Consent form was filled out by all participants.

\section{Authorship Contributions}

Concept: Fatih Uruç, Bekir Aras, Design: Fatih Uruç, Bekir Aras, Data Collection or Processing: Serkan Akan, Aytaç Şahin, Elif Uruç, Özgür Haki Yüksel, Analysis or Interpretation: Ahmet Ürkmez, Çağlar Yıldırım, Literature Research: Ahmet Ürkmez, Çağlar Yıldırım, Writing: Fatih Uruç, Bekir Aras.

Conflict of Interest: No conflict of interest was declared by the authors.

Financial Disclosure: The authors declared that this study has received no financial support.

\section{References}

1. Obesity and overweight, Fact sheet. №311: WHO; 2011. Available from: htttp:// www.who.int/mediacentre/factsheets/fs311/en.

2. Çıtak Akbulut $\mathrm{G}$, Özmen MM, Besler HT. Obezite çağın hastalı̆ı. TÜBiTAK Bilim ve Teknik Dergisi 2007;1-9.

3. World Health Organization. WHO global database on body mass index.

4. World Health Organization. Obesity and Overweight [acesso em 28 set 2012]. Disponivel em: http://www.who.int/mediacentre/factsheets/fs311/ en/

5. Satman I, Yilmaz T, Sengul A, Salman S, Salman F, Uygur S, Bastar I, Tutuncu Y, Sargin M, Dinccag N, Karsidag K, Kalaca S, Ozcan C, King H. Population-based study of diabetes and risk characteristics in Turkey: results of the turkish diabetes epidemiology study (TURDEP). Diabetes Care 2002;25:1551-1556. 
6. Satman I, Omer B, Tutuncu Y, Kalaca S, Gedik S, Dinccag N, Karsidag K, Genc S, Telci A, Canbaz B, Turker F, Yilmaz T, Cakir B, Tuomilehto J, Group T-IS. Twelve-year trends in the prevalence and risk factors of diabetes and prediabetes in Turkish adults. Eur J Epidemiol 2013;28:169-180.

7. Sjostrom L, Narbro K, Sjostrom CD, Karason K, Larsson B, Wedel H, Lystig T, Sullivan M, Bouchard C, Carlsson B, Bengtsson C, Dahlgren S, Gummesson $A_{1}$ Jacobson $P$, Karlsson J, Lindroos AK, Lonroth $H$, Naslund I, Olbers $T$, Stenlof K, Torgerson J, Agren G, Carlsson LM, Swedish Obese Subjects S. Effects of bariatric surgery on mortality in Swedish obese subjects. N Engl J Med 2007;357:741-752.

8. Colquitt JL, Picot J, Loveman E, Clegg AJ. Surgery for obesity. Cochrane Database Syst Rev 2009;CD003641.

9. Dixon JB, le Roux CW, Rubino F, Zimmet P. Bariatric surgery for type 2 diabetes. Lancet 2012;379:2300-2311.

10. Buchwald H, Oien DM. Metabolic/bariatric surgery worldwide 2011. Obes Surg 2013;23:427-436.

11. Taylor K. Bariatric surgery fact sheet. American society for metabolic and bariatric Surgery web site. Accessed February 23, 2011. Available from: http//www.asbs.org/Newsite07/media/asmbs_fs_surgery.pdf.

12. Bai SW, Kang JY, Rha KH, Lee MS, Kim JY, Park KH. Relationship of urodynamic parameters and obesity in women with stress urinary incontinence. J Reprod Med 2002;47:559-563.

13. Han MO, Lee NY, Park HS. Abdominal obesity is associated with stress urinary incontinence in Korean women. Int Urogynecol J Pelvic Floor Dysfunct 2006;17:35-39.

14. Wasserberg N, Haney M, Petrone P, Ritter M, Emami C, Rosca J, Siegmund K, Kaufman HS. Morbid obesity adversely impacts pelvic floor function in females seeking attention for weight loss surgery. Dis Colon Rectum 2007;50:2096-2103.

15. Brethauer SA, Hammel JP, Schauer PR. Systematic review of sleeve gastrectomy as staging and primary bariatric procedure. Surg Obes Relat Dis 2009;5:469-475.

16. Brethauer SA. Sleeve gastrectomy. Surg Clin North Am 2011;91:12651279, ix.
17. Buchwald H, Oien DM. Metabolic/bariatric surgery Worldwide 2008. Obes Surg 2009;19:1605-1611.

18. Karamanakos SN, Vagenas K, Kalfarentzos F, Alexandrides TK. Weight loss, appetite suppression, and changes in fasting and postprandial ghrelin and peptide-YY levels after Roux-en-Y gastric bypass and sleeve gastrectomy: a prospective, double blind study. Ann Surg 2008;247:401-407.

19. Melissas J, Daskalakis M, Koukouraki S, Askoxylakis I, Metaxari M, Dimitriadis E, Stathaki M, Papadakis JA. Sleeve gastrectomy-a "food limiting" operation. Obes Surg 2008;18:1251-1256.

20. Brethauer SA, Hammel JP, Schauer PR. Systematic review of sleeve gastrectomy as staging and primary bariatric procedure. Surg Obes Relat Dis 2009;5:469-475.

21. Gill RS, Birch DW, Shi X, Sharma AM, Karmali S. Sleeve gastrectomy and type 2 diabetes mellitus: a systematic review. Surg Obes Relat Dis 2010;6:707-713.

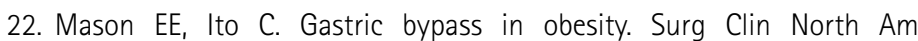
1967:47:1345-1351.

23. Vella VL, Jaffe W, Lidicker J, Meilahn J, Dandolu V. Prevalence of urinary symptoms in morbidly obese women and changes after bariatric surgery. J Reprod Med 2009;54:597-602.

24. Ranasinghe WK, Wright $T$, Attia J, McElduff $P$, Doyle $T$, Bartholomew M, Hurley K, Persad RA. Effects of bariatric surgery on urinary and sexual function. BJU Int 2011;107:88-94.

25. Palleschi G, Pastore AL, Rizzello M, Cavallaro G, Silecchia G, Carbone A. Laparoscopic sleeve gastrectomy effects on overactive bladder symptoms. J Surg Res 2015;196:307-312.

26. Merrell J, Brethauer S, Windover A, Ashton K, Heinberg L. Psychosocial correlates of pelvic floor disorders in women seeking bariatric surgery. Surg Obes Relat Dis 2012;8:792-796.

27. Snyder AR, Martinez JC, Bay RC, Parsons JT, Sauers EL, Valovich McLeod TC. Health-related quality of life differs between adolescent athletes and adolescent nonathletes. J Sport Rehabil 2010;19:237-248. 